\title{
GAMBARAN TINGKAT PENGETAHUAN DAN PERILAKU KEPALA KELUARGA MENGENAI PEMBERANTASAN SARANG NYAMUK AEDES AEGYPTI DI KELURAHAN SESETAN
}

\author{
Desak Ayu Ari Putri ${ }^{1}$, I Wayan Suarta Asmara
}

\begin{abstract}
Abstrak : According to data from the Denpasar city health office in 2019, the number of DHF sufferersin 2019 was 1,037 cases. Of the DHF cases in 2019, most occurred in South Denpasar with 373 cases, South Denpasar sub-district eith $I R=122.14$ per 100.00 population. The purpose of this stufy was to determine the level of knoeledge and behavior of family heads regarding the border of the Aedes aegypti mosquito nest in Sesetan Village. This type of research is descriptive. The sample size of this study was 96 houseolds. Characteristics of male dominant respondents 82 people (85.41\%), age is dominated by 43-54 years namely 54 people (56.25\%) and high school education (high school) is 47 people (48.96\%). The result showed that 96 heads of houseolds all had good knowledge about the eradication of Aedes aegypti mosquito nests. While the behavior of family heads to eradicate the Aedes aegypti mosquito breeding nests found 17 people (17.71\%) had sufficient behavior categories while the remaining 79 heads of houdeolds (82.29\%) had good behavior categories.
\end{abstract}

Keywords: Aedes aegypti Mosquito Nest Restrictions, Knowledge, Behavior, Family Head

\section{PENDAHULUAN}

Nyamuk merupakan jenis serangga yag termasuk kedalam ordo Diptera da family Culicidae. Nyamuk Aedes aegypti berkembangbiak dengan baik ditempat perindukan didalam maupun diluar rumah yaitu tempat penampungan air bersih misalnya bak mandi kaleng bekas ataupun semua container yang dapat menampung air bersih. Host alami DBD adalah manusia, agentnya adalah virus dengue yang termasuk kedalam family Flaviridae dan genus Flavivirus, terdiri dari 4 serotipe yaitu Den-1, Den-2, Den-3, dan Den4, ditularkan kemanusia melalui gigitan nyamuk yang terinfeksi, khususnya nyamuk Aedes aegypti dan Aedes albopictus yang terdapat hampir diseluruh pelosok Indonesia. ${ }^{1}$ Penyakit DBD dipengaruhi beberapa faktor antara lain, kebiasaan 
masyarakat yang menampung air bersih untuk keperluan sehari-hari, sanitasi lingkungan yang kurang baik, rumah pemukiman yang padat, penyediaan air bersih yang kurang, tidak menggunakan obat nyamuk dan kelambu pada saat tidur, pengelolaan sampah yang tidak baik, serta musim penghujan. $^{2}$

Meningkatnya jumlah kasus serta bertambahnya wilayah yang terjangkit disebabkan karena semakin banyaknya transportasi penduduk, adanya pemukiman baru, kurangnya perilaku masyarakat terhadap pembersihan sarang nyamuk, terdapatnya vektor nyamuk hampir diseluruh pelosok tanah air serta adanya empat sel tipe virus virus yang bersirkulasi sepanjang tahun. Faktor yang mempengaruhi kejadian penyakit demam berdarah dengue antara lain faktor host, lingkungan, perilaku hidup bersih dan sehat, serta faktor virusnya sendiri. Faktor host yaitu kerentanan dan respon, faktor lingkungan yaitu kondisi geografi (ketinggian dari permukaan laut, curah hujan, angin, kelembapan, musim), kondisi demografi (kepadatan, mobilitas, perilaku, adat istiadat)Masih tingginya kejadian DBD di Kelurahan Sesetan dapat dipengaruhi oleh faktor internal maupun eksternal seperti pengetahuan, sikap, perilaku masyarakat dalam memahami dan melakukan kegiatan kebersihan lingkungan rumah dalam pencegahan kejadian DBD. Selama ini pengetahuan masyarakat khususnya kepala keluarga di wilayah kerja UPTD Puskesmas I Dinas Kesehatan Kecamatan Denpasar Selatan dimana mengupayakan untuk mengatasi masalah kesehatan khususnya penyakit DBD, yang masih banyak berorientasi pada penyembuhan penyakit. Berbagai upaya dilakukan dalam mencegah meningkatnya kasus DBD namun masih banyak yang tidak sesuai harapan, sehingga masih banyaknya yang terkena penyakit $\mathrm{DBD}^{3}$. Adanya jumantik di puskesmas yang membantu masyarakat untuk melakukan pencegahan dengan cara PSN, maka dari itu pengetahuan dari masyarakat lebih melakukan PSN terlebih dahulu supaya berkurangnya status penyakit DBD tersebut. Pengetahuan dari masyarakat khususnya kepala keluarga sudah adanya peningkatan atau perubahan dari yang 
mengupayakan masalah kesehatan hingga melakukan pencegahan dengan cara PSN tersebut ${ }^{4}$.

Keberadaan jentik yang digambarkan dengan angka bebas jentik pada tahun 2019 di awal pada masing-masing Desa di wilayah kerja UPTD Puskesmas I Dinas Kesehatan Kecamatan Denpasar Selatan sebagai berikut : Kelurahan Panjer 91,84\%, Kelurahan Sesetan 90,11\%, dan Desa Sidakarya 92,43\%. Angka bebas jentik masingmasing Desa tersebut masih dibawah 95\%. Angka bebas jentik lebih atau sama dengan 95\% diharapkan penularan penyakit DBD dapat dicegah atau dikurangi ${ }^{5}$. Berdasarkan uraian diatas perlu dilakukan penelitian untuk mengetahui gambaran tingkat pengetahuan dan perilaku kepala keluarga pada Kelurahan Sesetan mengenai Pemberantasan Sarang Nyamuk Demam Berdarah Dengue di wilayah kerja UPTD Puskesmas I Dinas Kesehatan Kecamatan Denpasar Selatan.

Tujuan penelitian ini yaitu untuk Mengetahui gambaran tingkat pengetahuan dan perilaku kepala keluarga mengenai Pemberantasan
Sarang Nyamuk Aedes aegypti di Kelurahan Sesetan. Adapun tujuan khusus dalam penelitian ini yaitu : 1 . Untuk mengetahui tingkat pengetahuan kepala keluarga mengenai Pemberantasan Sarang Nyamuk Aedes aegypti di Kelurahan Sesetan. 2. Untuk mengetahui perilaku kepala keluarga mengenai Pemberantasan Sarang Nyamuk Aedes aegypti di Kelurahan Sesetan.

\section{METODE PENELITIAN}

Dalam penelitian ini, Jenis penelitian yang digunakan adalah penelitian deskritif. Penelitian deskritif adalah penelitaian yang dilakukan untuk mengetahui nilai 101iteratu mandiri, baik satu 101iteratu atau lebih (independent) tanpa membuat perbandingan, atau menghubungkan dengan 101iteratu lainnya ${ }^{6}$. Peneliti hanya melakukan wawancara mengenai tingkat pengetahuan dan perilaku kepala keluarga di Kelurahan Sesetan dalam upaya pemberantasan sarang nyamuk Aedes aegypti. ${ }^{7}$

Teknik pengumpulan data yang dilakukan dalam penelitian ini adalah 1. Data primer diperoleh dari wawancara menggunkan lembar 
quisioner terhadap kepala keluarga di wilayah Kelurahan Sesetan sebanyak 96 kepala keluarga tentang tingkat pengetahuan dan perilaku tentang Pemberantasan Sarang Nyamuk Aedes aegypti. 2. Data sekunder yang digunakan dalam penelitian ini adalah data yang didapatkan dari 102iterature terkait seperti buku maupun melalui internet.

Pengukuran pengetahuan dan perilaku kepala keluarga mengenai Pemberantasan Sarang Nyamuk Aedes aegypti ditentukan oleh jawaban yang diberikan oleh responden pada setiap nomor pertanyaan dengan ketentuan pertanyaan sebagai berikut :

1 Pengetahuan kepala keluarga terdiri dari 21 pertanyaan yang setiap pertanyaan terdiri 2 kategori jawabannya yaitu benar dan salah. Hasil dicocokan dengan kunci jawaban, apabila soal yang dijawab responden sesuai kunci jawaban nilai 1 dan jika tidak / salah nilai 0 . Jawaban responden tersebut dijumlahkan dan didapatkan nilai total jawaban responden kemudian untuk pemberian nilai, peneliti membuat interval kelas dengan berpedoman pada rumus Stargess.
Interval

$$
\begin{gathered}
=\frac{\text { skor tertinggi }- \text { skor terendah }}{\text { jumlah kelas }} \\
\text { interval }=\frac{21-0}{3}=7
\end{gathered}
$$

Nilai buruk $\quad: 0-7$

Nilai cukup $\quad: 8-14$

Nilai baik $\quad: 15-21$

2 Perilaku kepala keluarga yang terdiri dari 15 pertanyaan yang setiap pertanyaan terdiri dari 2 kategori jawaban yaitu YA nilai 1 dan TIDAK nilai 0 . Jawaban YA tersebut dijumlahkan dan didapatkan nilai total jawaban responden kemudian untuk pemberian nilai, peneliti membuat interval kelas dengan berpedoman pada rumus Stargess interval

$$
=\frac{\text { skor tertinggi }- \text { skor terendah }}{\text { jumlah kelas }}
$$

$$
\text { interval }=\frac{15-0}{3}=5
$$

Nilai buruk $\quad: 0-5$

Nilai cukup $\quad: 6-10$

Nilai baik $\quad: 11-15$

Data tersebut kemudian dibahas dengan cara deskriptif dan dikaitkan dengan teori-teori dan litenatur yang relevan. 
Berdasarkan

hasil

\section{HASIL DAN PEMBAHASAN}

1. Tingkat pengetahuan kepala keluarga mengenai pemberantasan sarang nyamuk Aedes aegypti

wawancara yang telah dilakukan terhadap 96 orang KK di Kelurahan Sesetan dengan menggunakan lembar kuesioner diperoleh hasil yang tersaji pada tabel berikut :

Tabel 7

Pengetahuan kepala keluarga mengenai pemberantasan sarang nyamuk Aedes aegypti

\begin{tabular}{cccc}
\hline & & \multicolumn{2}{c}{ Proposi } \\
\cline { 3 - 4 } No & Pengetahuan & Jumlah $(\mathrm{N})$ & Persentase (\%) \\
\hline 1 & Buruk & 0 & 0 \\
2 & Cukup & 1 & 01,04 \\
3 & Baik & 95 & 98,96 \\
\hline Total & & 96 & 100 \\
\hline
\end{tabular}

Berdasarkan tabel 7 diatas dapat dilihat bahwa dari 96 orang KK sebanyak 1 orang $(01,04 \%)$ memiliki kategori pengetahuan cukup, sedangkan sisanya 95 orang KK $(98,96 \%)$ memiliki pengetahuan baik.

\section{Berdasarkan hasil} wawancara yang telah dilakukan terhadap 96 orang KK di Kelurahan Sesetan dengan menggunakan lembar kuesioner diperoleh seluruh KK memiliki kategori tingkat pengetahuan baik mengenai Pemberantasan Sarang Nyamuk Aedes aegypti. ${ }^{8}$ Namun, dari 21 pertanyaan yang ada didalam kuesioner, nilai pertanyaan yang masih dibawah rata-rata antara lain :
Nyamuk penulara penyakit DBD berkembag biak dikotor, semestinya nyamuk aedes aegipty berkembang biak di air bersih, hal ini cukup banyak ditemukan di lapangan ${ }^{9}$. Fogging atau diasap lebih efektif menanggulangi penyakit DBD dibandingkan dengan cara PSN, masih banyak masyarakat memiliki pandangan bahwa penyemprotan dengan foging lebih baik $^{4}$. Menaburkan bubuk abate dibak mandi termasuk kegiatan $\mathrm{PSN}^{8}$. Memperbaiki saluran atau talang air termasuk bagian kegiatan PSN dan menutup lubang pohon termasuk kegiatan PSN serta mendaur ulang barang bekas termasuk kegiata PSN. 
Kegiatan memelihara ikan di kolam termasuk kegiatan $\mathrm{PSN}^{10}$.

2. Perilaku kepala keluarga mengenai pemberantasan sarang nyamuk Aedes aegypti

Berdasarkan

hasil wawancara yang telah dilakukan terhadap 96 orang KK di Kelurahan Sesetan dengan menggunakan lembar kuesioner diperoleh hasil yang tersaji pada tabel berikut :

Tabel 9

Perilaku kepala keluarga mengenai pemberantasan sarang nyamuk Aedes aegypti

\begin{tabular}{cccc}
\hline & & \multicolumn{2}{c}{ Proposi } \\
\cline { 3 - 4 } No & Perilaku & Jumlah $(\mathrm{N})$ & Persentase (\%) \\
\hline 1 & Buruk & 0 & 0 \\
2 & Cukup & 17 & 17,71 \\
3 & Baik & 79 & 82,29 \\
\hline Total & & 96 & 100 \\
\hline
\end{tabular}

Berdasarkan tabel 6 diatas dapat dilihat bahwa dari $96 \mathrm{KK}$ sebanyak $17(17,71 \%)$ memiliki kategori perilaku cukup, sedangkan sisanya sebanyak 79 KK $(82,29 \%)$ memiliki kategori baik. Perilaku masyarakat di kelurahan Sesetan dalam pemberantasan sarang nyamuk dalam katagori baik $^{11}$

\section{SIMPULAM DAN SARAN}

\section{A. Simpulan}

Berdasarkan pembahasan di atas dapat disimpulkan sebagai berikut :

1. Tingkat pengetahuan dari 96 KK mengenai Pemberantasan Sarang Nyamuk Aedes aegypti di Kelurahan Sesetan diperoleh 1 KK $(01,04 \%)$ memiliki kategori cukup dan 5 orang KK $(98,96 \%)$ memiliki kategori tingkat pengetahuan baik mengenai Pemberantasan Sarang Nyamuk Aedes aegypti. 2. Perilaku mengenai Pemberantasan Sarang Nyamuk Aedes aegypti dari 96 orang KK di Kelurahan Sesetan diperoleh sebanyak 17 $(17,71 \%)$ memiliki kategori perilaku cukup, sedangkan sisanya sebanyak 79 KK (82,29\%) memiliki kategori perilaku baik. 


\section{B. Saran}

1. Sebaiknya masyarakat mempertahankan pengetahuan dan meningkatkan perilaku mengenai Pemberantasan Sarang Nyamuk Aedes aegypti dengan mendaur ulang barang bekas yang dapat menampung air hujan, menaburkan abate sesuai dengan aturan pakai dan menanam tanaman pengusir nyamuk.

2. Untuk Kepala Lingkungan dimasing-masing banjar sebaiknya lebih meningkatkan dan memperbanyak sosialisasi mengenai PSN kepada masyarakat.

\section{DAFTAR PUSTAKA}

1. Depkes RI. Perilaku dan

Siklus Hidup Nyamuk Aedes

Aegypti Sangat Penting

Diketahui dalam Melakukan

Kegiatan Pemberantasan

Sarang Nyamuk Temasuk

Pemantauan Jentik Berkala. (2004).

2. Anwar, A., \& Rahmat, A.

Hubungan Kondisi

Lingkungan Fisik dan

Tindakan PSN Masyarakat
Dengan Container Index

Jentik Aedes aegyptidi

Wilayah Buffer Bandara

Temindung Samarinda.

Samarinda. Hygiene E1 No.2, (2015).

3. Selatan, U. P. I. D. K. K. D.

Profil UPTD Puskesmas I

Dinas Kesehatan Kecamatan

Denpasar Selatan Tahun 2019. (2019).

4. Ambarawati, S. D., \& Astuti,

D. Fogging Sebagai Upaya

Untuk Memberantas Nyamuk

Penyebar Demam Berdarah Di

Dukuh Tuwak Desa Gonilan,

Kartasura, Sukoharjo. warta

130-138 (2006).

5. Bali, D. K. P. Profil Kesehatan Provinsi Bali Tahun 2019.

(2019).

6. Sugiyono. Statistik Untuk Penelitian. (2013).

7. Wawan, D. M. dan A. Teori dan pengetahuan Sikap dan Perilaku Manusia,. (2010).

8. Putri, I. A. Hubungan Tempat Perindukan Nyamuk dan Perilaku Pemberantasan Sarang Nyamuk (PSN) dengan Keberadaan Jentik Aedes aegyptidi Kelurahan Benda 
Baru Kota Tangerang Selatan. (2015).

9. Husna, R. N., Wahyuningsih, N. E., \& D. Hubungan

Perilaku 3 M Plus dengan Kejadian Demam Berdarah Dengue di Kota Semarang. Kesehat. Masy. 4 N0.5, (2015).

10. Basri, S., \& E. H. Penggunaan Abate dan Bacillus Thuringensis Var. Israelensis di Kantor Kesehatan
Pelabuhan Kelas I Samarinda

Wilayah Kerja Sanggata

Terhadap Kematian Larva

Aedes Sp. Makasar. Al-Sihah

Ix,N0.1, (2017).

11. Kriastuti, D. Pengaruh

Pengetahuan dan Sikap

Terhadap Perilaku Hygiene

Penjamah Makanan di Kantin

SMA Muhamaddiyah 2

Surabaya. Boga 5 N0.2, (2016). 